\title{
Charging and Discharging Battery System Automation in Simple Wind Power Plant
}

\author{
M Chw Al Fajar ${ }^{1}$, Ahmad Al Afif ${ }^{2}$, Ahmad Idris ${ }^{3}$, Adhytya Dhava Shalsa Putra ${ }^{4}$ \\ \{mchwalfajar@gmail.com¹, ahmadalafif98@gmail.com², idrisahmad8422@gmail.com³, \\ adhytyadhava2@gmail.com $\left.{ }^{4}\right\}$ \\ Electrical Engineering, Faculty of Science and Technology, University of Al Azhar Indonesia \\ Jakarta, Indonesia.
}

\begin{abstract}
Electrical energy is the energy that is easyly obtained by conversion of other energy, such as wind into electricity. Wind power is an alternative environment friendly energy generation. In its application, alternative power plants need a control system to regulate the process of energy storage and the distribution of electrical energy. The working principle of this system is to do automation in managing the process of storing electrical energy in the battery (charging) by providing electric current continuously until it reaches full charge and terminate storage of electrical current (discharging) the battery when the charge in the battery has reached the maximum point and control the load such as lights to turn on and turn off automatically.
\end{abstract}

Keywords: Alternative Electrical Energy, Battery, Charging, Control System, Discharging, Energi Listrik Alternatif.

\section{Introduction}

In everyday life, electricity is an important requirement to support all the activities that people do, such as in households for cooking, in industry to operate the machine, as well as many other things that in practice relies heavily on electric energy. With such a large requirement in electricity use, it is very necessary to try to get elecricity from renewable energy to reduce from using fossil energy which will eventually run out. One alternative to electricity generation is to convert kinetic energy from wind to converted become elecrical energy.

The generation of electrical energy derived from wind is one of the alternatives for the generation of electrical energy that is in accordance with the natural conditions of Indonesia which are traversed by wind movements [1]. Wind is kinetic energy which can be found in various places. One of the places with fast wind movement is along the toll road. With such wind potential, this can be used for application in the generation of wind power.

In the application, wind power generation there are aspects that must be considered to obain the maximum results of electrical energy is a form of the windmill blades. Windmill have two types, windmill with Horizontal Axis Wind Turbine (HAWT) and windmill with Vertical Axis Wind Turbine [2]. The two types of windmills have different characters, HAWT can produce rotation at a generaor with greater torque because the construction of horizontal blade windmill must be placed in a high place and the impact will take more space. The construction of vertical blade windmill it doesn't need to be placed in a high place and the 
blade used isn't large and take more space, which is very appropriate when applied along the highway.

Wind power plants that are implemented along toll roads will be very effective if given an automatic control system to reduce maintenance costs. Wind power plants are power plants which are very dependent on wind speed, so that when the wind does not blow, the power plant cannot produce electricity. The solution to these problems is adding the battery on the system, and provide control system to perform battery charging and discharging process automatically.

\section{Design and Methodology}

Wind power plant is a power plant that has outputs that depend heavily on the speed of the wind. The working principle of this power plant is to transform kinetic energy of wind into electrical energy by a process when the wind through the windmill, blades will turn a generator to produce electricity.

The electrical energy produced by the generator can be used to charge the power on the battery needs to be adjusted first, such as adjusting the voltage and current used. When the voltage and current produced are appropriate, the automatic control system can control the electrical energy from generator to battery, and from battery to load, or from generator to load [3].

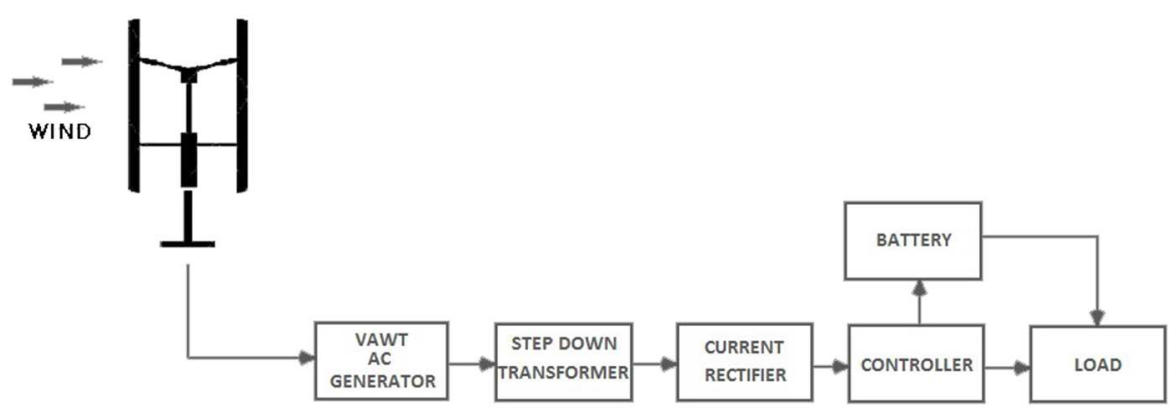

Figure 1. Overview Wind Turbine System.

\subsection{Battery}

In the electricity generation system, the battery is the part needed to store the electrical energy that has been produced by the generator. Electric energy in batteries is obtained from chemical energy conversion. In the battery there are elements, namely the primary element that performs a chemical reaction and causes the movement of electrons from the negative electrode (cathode) to the positive electrode where the direction of its movement cannot turn around. The electrical energy produced by the generator will be wasted if the electric load 
does not require energy. In addition, the existence of a battery can also anticipate if the wind does not blow, which causes the load not getting electricity when needed [4].

The battery used in this automatic charging control system is $12 \mathrm{~V}$ battery with a capacity of $7 \mathrm{Ah}$. In the battery there are cells with each cell having approximately voltage of $2.1 \mathrm{~V}$ and installed in series. So for $12 \mathrm{~V}$ battery it has a real capacity in $12.8 \mathrm{~V}$. To find out charging limit as a reference for the control system the device works well in providing control of the charging process, the equivalent equation of the battery can be determined as:

$$
\mathrm{V}_{\text {bat }}=\mathrm{V}_{\mathrm{i}}-\mathrm{R}_{\mathrm{i}} \mathrm{I}_{\mathrm{b}}
$$

With:

$$
\begin{array}{ll}
\mathrm{V}_{\text {bat }} & =\text { Battery output voltage }(\mathrm{V}) \\
\mathrm{V}_{\mathrm{i}} & =\text { Internal voltage battery }(\mathrm{V}) \\
\mathrm{R}_{\mathrm{i}} & =\text { Internal resistance }(\mathrm{Ohm}) \\
\mathrm{I}_{\mathrm{b}} & =\text { Battery current }(\text { Ampere) }
\end{array}
$$

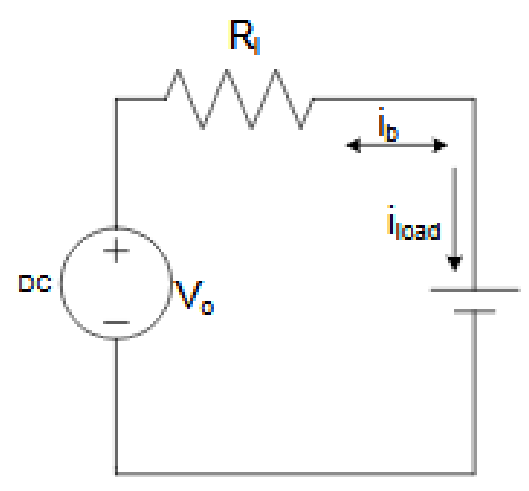

Figure 2. Battery Equivalent Circuit.

In the figure of circuit equivalent battery above, consisting the source voltage from power plant, internal resistance of the battery, and the battery. Using the equivalent circuit above, it can be determined that the voltage can be used to charge battery, according to the standard of the manufacturer of the empty charged battery $\left(\mathrm{V}_{0}\right)$ is 11.2 Volts and the battery with full charge is 12.8 Volt [5]. Process of charging an electric charge on the battery needs to determine the value of the resistance in the battery and the electric current that is suitable to be used to battery charging process. Internal resistance in the battery to be used to battery charging process. The internal resistance of the battery and the electric current value can be found with the equation:

$$
\mathrm{I}_{\mathrm{b}}=\text { Battery Capacity }(\mathrm{Ah}) \times 10 \%=7 \mathrm{Ah} \times 10 \%=0.7 \mathrm{~A}
$$




$$
\mathrm{Ri}=\frac{\text { Vbat }-\mathrm{Vi}}{\mathrm{Ib}}=\frac{12.8-11.2}{0.7}=2.28 \Omega
$$

With:

$\mathrm{I}_{\mathrm{b}} \quad=$ Current of charging process (A)

$\mathrm{R}_{\mathrm{i}} \quad=$ Internal resistance battery

$\mathrm{V}_{\text {bat }}=$ Full battery

$\mathrm{V}_{\mathrm{i}} \quad$ Empty battery

So that it can be used to do the charging process on a 12 volt battery with a full voltage of 12.8 volts. The amount of voltage needed can be determined using the calculation from equation (1) as:

$$
\begin{aligned}
V_{i} & =V_{\text {bat }}+\left(R_{i} I_{b}\right) \\
& =12.8+(2.28 \times 0.7) \\
& =14.4 \text { volt }
\end{aligned}
$$

\subsection{Battery Charger}

Charging is a conversion process to convert electricity into chemical energy by storing it in the battery cell. This is to keep the supply of electrical resources fully maintained, so that when electricity is needed it can be directly used.

In the charging process there are two types of charging methods, Constant Current Charge and Constant Potential Charge. Constant Current Charge is the process charging battery by flowing the current from the charger circuit to the battery with a fixed current. While Constant Potential Charge is the process charging battery with a fixed voltage but the current is always changing [3]. The filling process with the Constant Potential Charge method is illustrated by the graph as follows: 


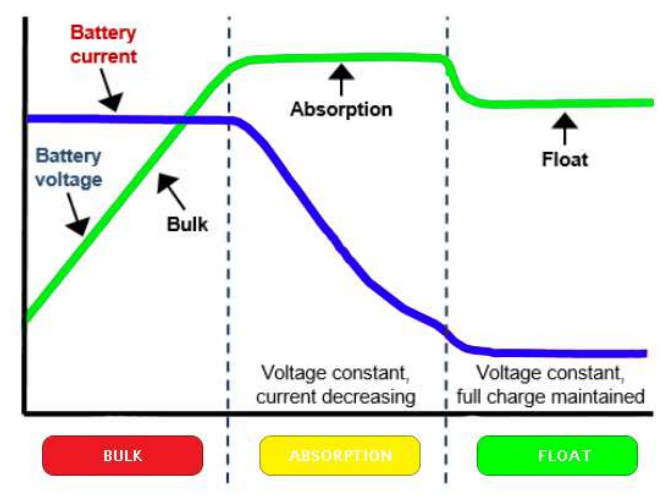

Figure 3. Constant Potential Charge Methode.

From the graph above there are three stages in the Constant Potential Charge method. First is the Bulk Charge stage, in this process the current is constant but the voltage will rise slowly from low voltage to the standard voltage, for a 12 volt battery the charging standard is between 12.8 - 14.4 volts, and the standard current flow is $10 \%$ of the total capacity of the battery. When the battery voltage has reached the standard voltage of 14.4 volts, the Bulk stage is complete.

In the second stage is the Absorption stage, in this process the voltage is constant at 14.4 volts and the constant current in the previous stage will slowly be lowered to reach the standard battery flow point, which is stated to be full at $5 \%$ of the total battery capacity. When the charging process has flowed below the full standard battery current, the Absorption stage is complete and the battery is $100 \%$ full.

In the third stage is the Floating stage, in this process is an addition from the previous stage to keep the battery voltage in $100 \%$ full condition, because the battery voltage will drop by several volts when the charging process is stopped [6].

\subsection{Charging and Discharging Control}

The Charging control process is a control process to charge the battery so that it matches the stages of Bulk, Absorption and Float. The controller will keep the current and voltage at the correct level to get the best level of efficiency in the charging process. Discharging process is a process that functions to protect the battery because if the battery has reached full condition but the charging process is still being carried out, then it can damage the cells inside the battery. Simply the control process from battery charging and discharging is carried out as follows: 


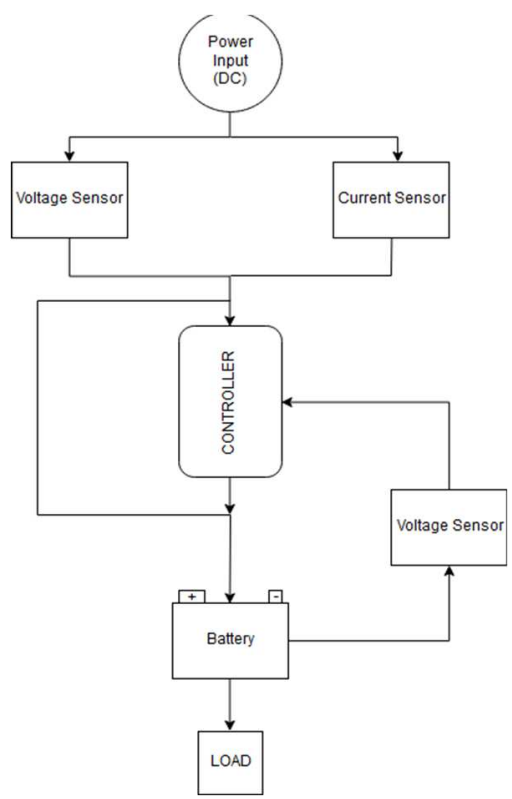

Figure 4. Workflow and Charging - Discharging Components.

From the workflow above can be seen if the control system will control the electricity generated by the generator. Electricity generated by the generator will pass through the current and voltage sensors which are also connected to the microcontroller. The microcontroller will read the value of the current and voltage then the value is stored on the microcontroller in the form of data to be used as a control parameter. Simultaneously, the current and voltage will charge the battery and a voltage sensor which also acts as feedback to monitor the state of the battery, the data will also be stored in the microcontroller to perform the next control function properly [7].

The control system when the battery is full will discharge process. The voltage sensor connected to the battery will read and the data will be forwarded to the microcontroller for discharge process. For a more detailed circuit control system of charging - discharging process are as follows: 


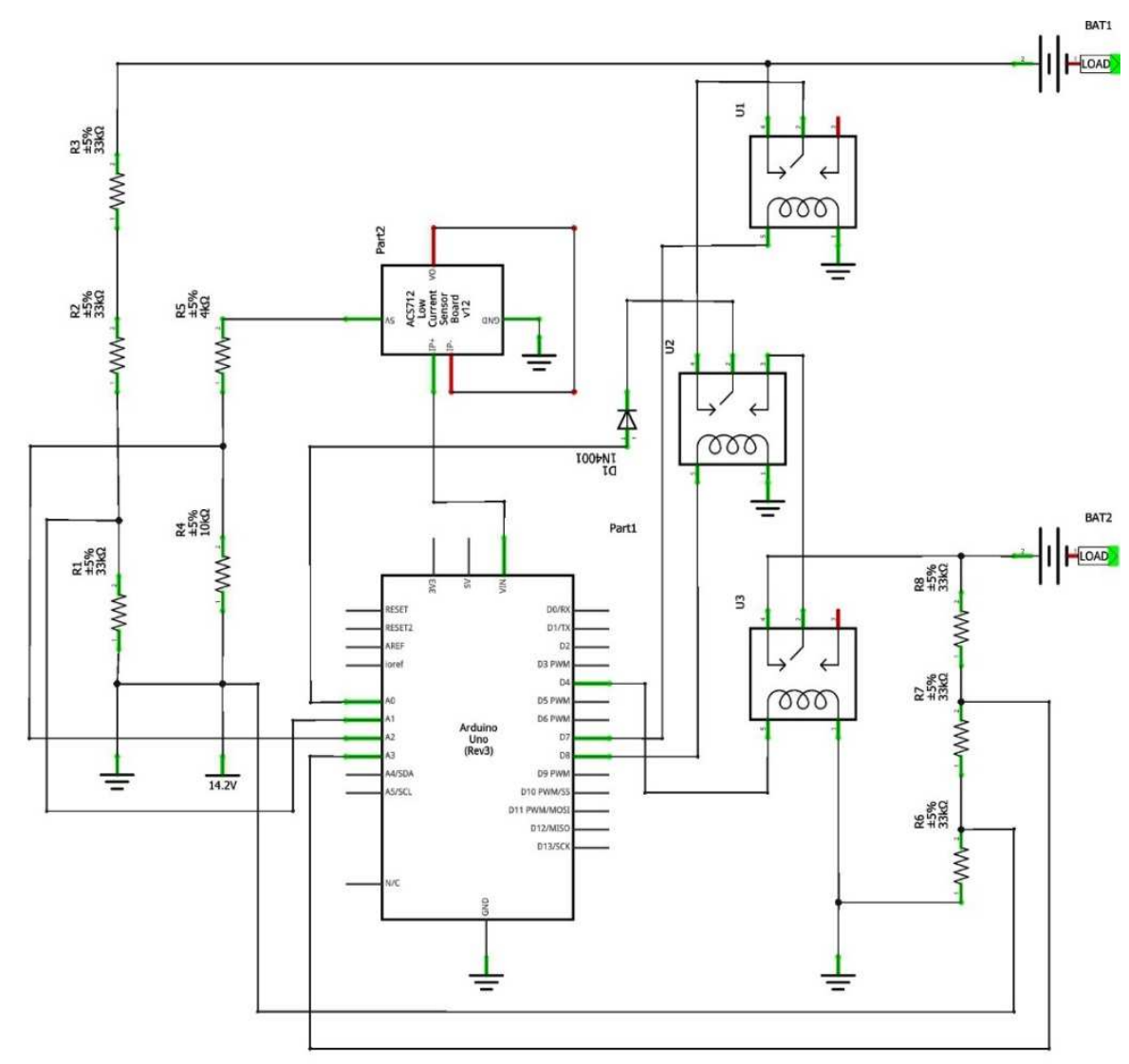

Figure 5. Charging - Discharging Control System Wiring Diagram.

In the charging control system - discharging based on the wiring diagram above there are several main components such as Arduino, Relay module, INA219 sensor (a combination of voltage sensors and current sensors), several resistors and diodes. The process control system that will run is when the electricity comes from generators will be read by the sensor pin INA219 at A2, the current and voltage sensors will be governed by the microcontroller to fit the appropriate threshold in the charging process [3]. Data obtained from the INA219 sensor is used for further instructions which will be forwarded to relay 1 via pin A0. before entering the relay there is a rectifier diode as current protection does not reverse. For sample coding from current and voltage controls using INA219 sensors are as follows:

\#include $<$ Wire.h $>$

\#include $<$ Adafruit_INA219.h $>$

const int INA_addr $=0 \times 40$;

Adafruit_INA219 ina219(INA_addr); 


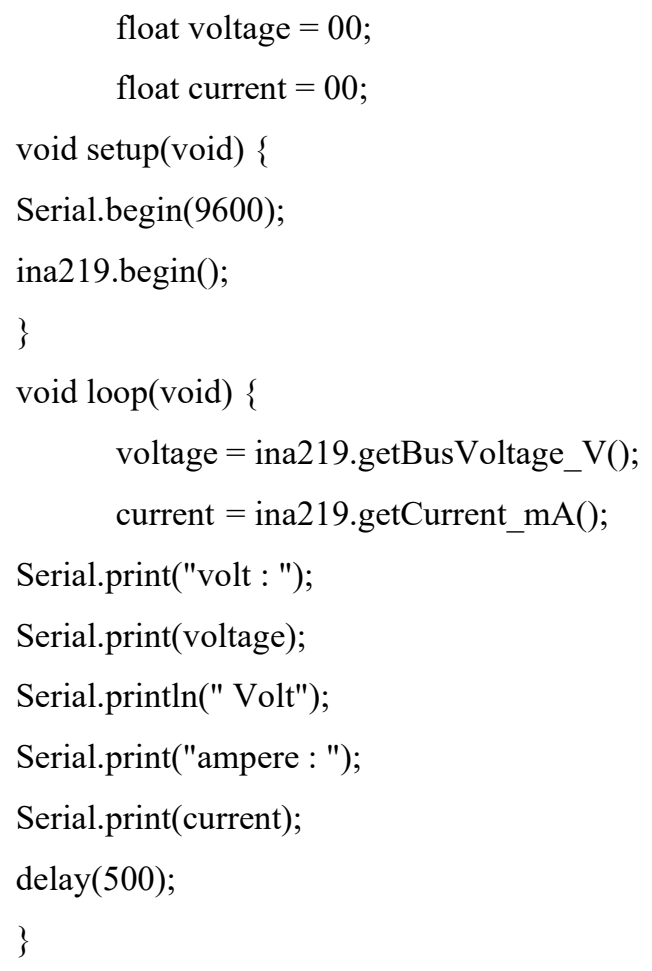

INA219 sensor is an alternative sensor to replace the performance of the ACS712 current sensor and voltage sensor. The use of the INA219 sensor on the microcontroller requires additional libraries that can be downloaded directly from the developer, Adafruit. Furthermore, data from the INA219 sensor in the form of voltage and current from the battery will be received by the microcontroller to carry out the next instruction, relay activation.

Relay on this system has 3 modules, the first relay is a relay to control electricity going to battery 1 or battery 2 , in this case it has been initialized if relay 1 "HIGH" then electricity will go to battery 1 and if relay 1 "LOW" then electricity will flow to the battery 2. Sample coding from relay activation 1 is as follows:

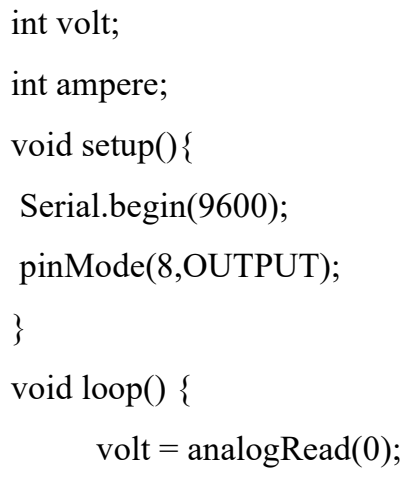




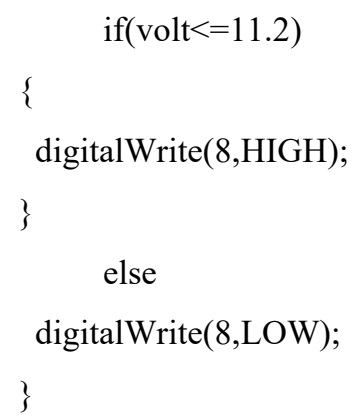

Electricity that has passed through the relay will go to the battery for the charging process. During the charging process, the INA219 sensor will always scan the voltage and current on the battery. In this control system, battery 1 is prioritized to be charged first, then when battery 1 is full, the relay will change the electricity flow to the battery charging process 2. Whereas the discharging process will be carried out when the battery reaches 14.4 volts, relay 1 and relay 2 will alternately disconnect electricity according to battery conditions[8].

\section{Result and Analysis}

Control system charging and discharging battery is a form of control to provide protection to the battery during charging and discharging. According with the wiring diagram, input voltage for charging 12 volt battery with a 7Ah capacity is a maximum in 14.4 volts with a current of 0.7 amperes. The current and voltage will pass through the relay which is a switching component. There are 3 relays on the control system and has two conditions for giving current and voltage instructions whether to go to battery one or battery two. The charging process will take place continuously until the sensor detects the voltage on the battery at maximum voltage and the relay will conduct discharging on the battery and move to process charging on the second battery.

The process of charging on a 12 volt battery and 7Ah capacity, obtains data for the charging duration by setting the voltage at 14.4 volts for a full 12.8 volt battery charging voltage which will be connected to the battery as follows:

Table 1. Result Analysis Battery charging Control System.

\begin{tabular}{llll}
\hline Voltage (V) & Current (A) & Duration (hour) & Capacity (Ah) \\
\hline 11.2 & 0.7 & 1 & 0.7 \\
11.5 & 0.58 & 2.5 & 1.45 \\
11.8 & 0.48 & 4 & 3.37 \\
12.1 & 0.34 & 5.5 & 5.24 \\
12.4 & 0.15 & 7 & 6.29 \\
12.8 & 0.07 & 10 & 6.99 \\
\hline
\end{tabular}


Based on the result analysis of the battery charging control system, the battery is charged at 11.2 volts in the first hour and the voltage gradually rises to a maximum voltage of 12.8 volts after 10 hours. The battery charging voltage graph for time is obtained as follows:

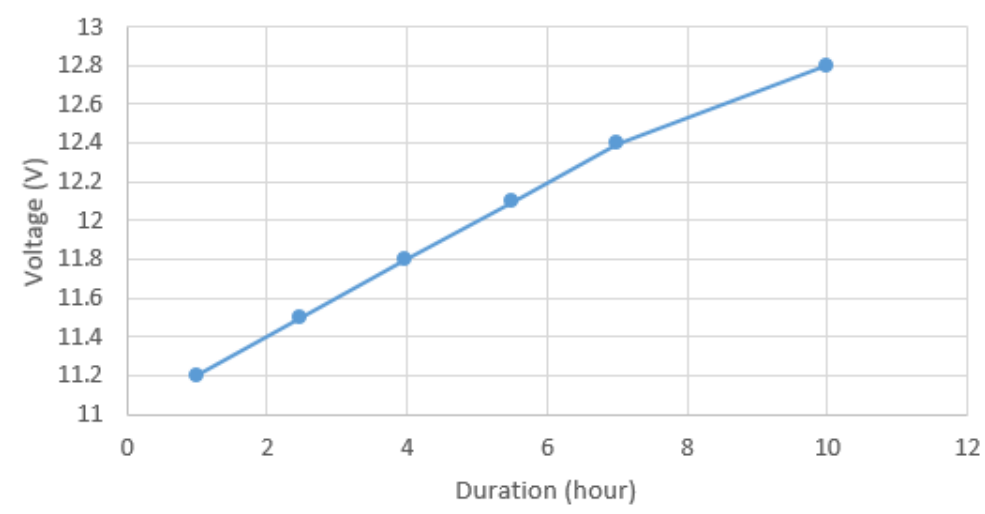

Figure 6. Voltage to Duration Graphic from Battery Charging.

During the charging process, the voltage increases from 11.2 volts to 12.8 volts according to the initial setting of the charging voltage 14.4 volts, the relay will disconnect the battery charging current when it reaches 12.8 volts.

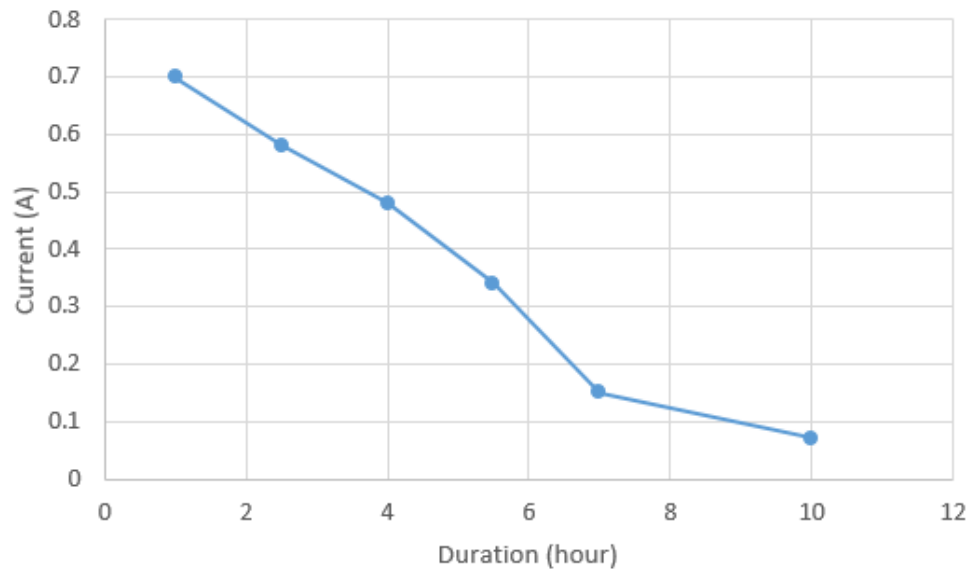

Figure 7. Current to Duration Graphic from attery Charging.

On the Current chart, the charging duration can be seen if the current starting at $0.7 \mathrm{~A}$ decreases periodically to reach $0.07 \mathrm{~A}$ when the battery charge is full. 


\section{Summary}

The results of designing a conrol system of charging and discharging battery using an Atmega328 based microcontroller are:

1. Can protect the battery from overcharge, which can speed up the damaged battery.

2. The us of a microcontroller can adjust teh voltage level in the charging process and will stop charging when the battery has reached full charge at a voltage of 12.8 volts.

3. By using automatic switching control, it can be used to anticipate the output of a power generator that might not be able to process the charging on a 12 volt battery in series, which requires a voltage of approximately 24.8 volts.

4. During the charging process, the voltage will be inversely proportional to the electric current. If at the start of charging the voltage is 11.2 volts and stops at 12.8 volts, then the current starts at 0.7 amperes and ends at 0.07 Ampere. 


\section{References}

[1] R. Yunginger and N. S. Nawir, “Analisis Energi Angin Sebagai Energi Alternatif Pembangkit Listrik Di Kota Di Gorontalo,” vol. 15, pp. 1-15, 2015.

[2] L. Hogberg, "Automated electric control of a vertical axis wind turbine in insland operation," 2009.

[3] F. Mahmuddin, A. M. Yusran, and S. Klara, "On the use of an Arduino-based controller to control the charging process of a wind turbine," AIP Conf. Proc., vol. 1814, no. December, 2017.

[4] F. Husnayain, "PROFILE OF 12-V VOLTAGE-REGULATED LEAD-ACID BATTERY Table of Contents," 2017.

[5] W. Budiman and N. Hariyanto, "Perancangan dan Realisasi Sistem Pengisian Baterai 12 Volt 45 Ah pada Pembangkit Listrik Tenaga Pikohidro di UPI Bandung," Bandung Inst. Teknol. Nas., vol. 2, no. 1, pp. 1-12, 2014

[6] "PENGISI BATERAI $10 \mathrm{Ah}$ - $100 \mathrm{Ah}$ DENGAN AUTODETEKSI AKI RUSAK BERBASIS ARDUINO TUGAS AKHIR," 2018.

[7] A. Ndiaye, C. M. F. Kébé, V. Sambou, and P. A. Ndiaye, "Development of a Charge Controller Dedicated to the Small Wind Turbine System," Energy Environ. Res., vol. 4, no. 3, 2014.

[8] T. B. O. Simanjuntak, G. M. C. Mangindaan, and M. Pakiding, "Rancang Bangun Sistem Kontrol Otomatis Dan Pengamatan Kondisi Baterai Pada Sistem Pembangkit Listrik Berbasis

Microcontroller," J. Tek. Elektro dan Komput., vol. 6, no. 2, pp. 63-68, 2017. 